\title{
1 Spatial organization of the kelp microbiome at micron scales
}

2 S. Tabita Ramirez-Puebla* ${ }^{\mathrm{a} *}$, Brooke L. Weigel ${ }^{\mathrm{b}}$, Loretha Jack ${ }^{\mathrm{a} *}$, Cathleen Schlundt ${ }^{\mathrm{a} *}$, Catherine

3 A. Pfister ${ }^{\mathrm{c}}$, Jessica L. Mark Welch ${ }^{\mathrm{a} \#}$

4 a Josephine Bay Paul Center for Comparative Molecular Biology and Evolution, Marine

5 Biological Laboratory, Woods Hole, MA, USA

$6{ }^{\mathrm{b}}$ Committee on Evolutionary Biology, University of Chicago, Chicago, IL, USA

$7 \quad$ cDepartment of Ecology and Evolution, University of Chicago, Chicago, IL, USA

8 Running Head:

9 Imaging the kelp microbiome

10 \#Address correspondence to Jessica L. Mark Welch, jmarkwelch@mbl.edu

11 *Present address: S. Tabita Ramirez-Puebla, The Forsyth Institute, 245 First Street, Cambridge,

12 MA 02142, USA. Loretha Jack, University of Wisconsin, Milwaukee, WI, USA. Cathleen

13 Schlundt, GEOMAR Helmholtz Center for Ocean Research Kiel, Duesternbrooker Weg 20,

1424105 Kiel, Germany. 


\section{Abstract}

16 Macroalgae are colonized by complex and diverse microbial communities that are distinct from

17 those on inert substrates, suggesting intimate symbioses that likely play key roles in both

18 macroalgal and bacterial biology. Canopy-forming kelp fix teragrams of carbon per year in

19 coastal kelp forest ecosystems, yet little is known about the structure and development of their

20 associated microbial communities. We characterized the spatial organization of bacterial

21 communities on blades of the canopy-forming kelp Nereocystis luetkeana using fluorescence in

22 situ hybridization and spectral imaging with a probe set combining phylum, class and genus-

23 level probes to target $>90 \%$ of the microbial community. We show that kelp blades host a dense

24 microbial biofilm, generally less than $20 \mu \mathrm{m}$ thick, in which disparate microbial taxa live in close

25 contact with one another. The biofilm is spatially differentiated, with tightly clustered cells of the

26 dominant symbiont Granulosicoccus sp. (Gammaproteobacteria) close to the kelp surface and

27 filamentous Bacteroidetes and Alphaproteobacteria relatively more abundant near the biofilm-

28 seawater interface. Further, a community rich in Bacteroidetes colonized the interior of kelp

29 tissues. Microbial community structure and cell density increased along the length of the kelp

30 blade, from sparse microbial colonization of newly produced tissues at the meristematic base of

31 the blade to an abundant microbial biofilm on older tissues at the blade tip. Finally, kelp from a

32 declining population hosted fewer microbial cells compared to kelp from a stable population,

33 indicating that biofilms are characteristic of health and that biofilm loss may be related to the

34 condition of the host. 


\section{Importance}

36 The microbial community coating the surfaces of macroalgae may play a key but underexplored

37 role both in the biology of the macroalgal host and in the biogeochemistry of the coastal ocean.

38 We show that photosynthetic blades of the canopy-forming kelp Nereocystis luetkeana host a

39 complex microbial biofilm that is both dense and spatially differentiated. Microbes of different

40 taxa are in intimate cell-to-cell contact with one another; microbial cells invade the interior of

41 kelp cells as well as cover their external surfaces; and a subset of the surface microbiota projects

42 into the water column. These results highlight the potential for metabolic interactions between

43 key members of the kelp microbiome as well as between microbes and their host. The dense

44 layer of microbes coating the surface of the kelp blade is well-positioned to mediate interactions

45 between the host and surrounding organisms and to modulate the chemistry of the surrounding 46 water column. 


\section{Introduction}

Macroalgae are foundational members of their local ecosystems, where they provide animal habitat and nursery areas (Lamy et al. 2020), contribute to primary productivity (Wilmers et al. 2012), and modify surrounding seawater chemistry (Pfister et al. 2019). The surfaces of macroalgae are associated with microbial communities that may play a key but underexplored role in macroalgal biology. The surface of macroalgae is frequently colonized by a microbial community that is spatially well-positioned to act as a mediator of algal metabolic exchange with the environment. As dominant members of temperate coastal oceans, brown algae known as kelp host microbial communities distinct from those in surrounding seawater (Michelou et al. 2013, Chen \& Parfrey 2018, Weigel and Pfister 2019) and from rocky substrates (Lemay et al. 2018), indicating that kelp may possess mechanisms for selecting or recruiting a unique subset of water column microbes, while preventing fouling or biofilm establishment of many others. Further, kelp metagenomes contain a high abundance of microbial motility genes (Minich et al. 2018) and kelp tissue only several days old becomes colonized by bacteria (Weigel and Pfister 2019). Microbial community changes have been linked to algal host health (Marzinelli et al. 2015) and environmental stressors (Minich et al. 2018). While the functions of macroalgal microbiomes are still being elucidated, surface-associated microbes can metabolize algal polysaccharides (Martin et al. 2015, Lin et al. 2018) and in seagrasses, functionally important metabolite exchanges between host and microbes have been demonstrated (Tarquinio et al. 2018). Despite the potential for macroalgal-associated microbial communities to affect nutrient exchange, biofouling, disease and even host development (Egan et al. 2013), we know little about the composition and development of macroalgal microbial communities.

Imaging of microbial community organization reveals the micrometer-scale localization of taxa relative to one another and relative to host tissue and other landmarks such as the surface of the biofilm. In a complex microbial community characterized by cross-feeding and metabolic interactions among diverse partners, localization provides clues about the micro-habitats and metabolic partners that foster the growth of particular microbes. Localization is key because microbes interact primarily with other microbes within a distance of a few microns or tens of

75 microns, particularly in environments characterized by fluid flow (Kolenbrander et al. 2010, 76 Cordero and Datta 2016, Dal Co et al. 2019). Thus, visualizing the spatial structure of a 
77 microbial biofilm contributes greatly to our understanding of host-microbe and microbe-microbe 78 interactions.

79 We investigated the micron-scale spatial organization of microbial communities living on

80 photosynthetic blades of bull kelp, Nereocystis luetkeana. Bull kelp are a highly productive

81 component of the northeast Pacific Ocean, creating vast underwater forests from southern

82 California to Alaska. This annual kelp displays extraordinarily high growth rates, with

83 photosynthetic kelp blades growing outwards from the kelp thallus at rates of $0.5-2 \mathrm{~cm}$ per day

84 (Weigel and Pfister 2019) and reaching heights greater than $40 \mathrm{~m}$. This rapid growth permitted

85 us to ask how microbial community spatial structure and diversity changes from newly produced

86 tissue at the base of the blade to months-old tissue at the blade tip. We used Combinatorial

87 Labeling and Spectral Imaging - Fluorescence in situ Hybridization (CLASI-FISH; Valm et al.

$882011,2012)$ to investigate microbial community spatial structure on $N$. luetkeana blades during

89 its rapid summer growth. In addition, we compared the microbial biofilm structure from a

90 healthy $N$. luetkeana population to a geographically distinct population that has been in decline

91 in recent years (Pfister et al. 2017, Berry et al. 2020). We demonstrate that the composition of

92 the kelp microbiome displays repeatable spatial structure (i.e. microbiota changes over micron-

93 scale distances from the blade surface), that colonization density correlates with the age of the

94 blade, and that bacterial diversity and density are related to the state of health of the kelp. 


\section{Results}

\section{Development of probe set and sample preparation methodology for CLASI-FISH on kelp}

To investigate the community structure of the kelp microbiota over time and in kelp populations at different locations in Washington State, we collected kelp blade tissue samples (n

$99=6$ individuals) from two sites reported in Weigel and Pfister (2019): Squaxin Island, in

100 Southern Puget Sound, and Tatoosh Island, on the outer coast of the Olympic Peninsula. In this 101 study, we carried out CLASI-FISH and imaging on a total of 15 samples: 3 from a declining 102 population at Squaxin Island (Berry et al. 2020) and 12 from a persistent population at Tatoosh 103 Island (Table S1). Squaxin Island kelp were sampled once on 21 June 2017, while on Tatoosh 104 Island we collected a time series consisting of 5 collection days from June to August 2017 (Table $105 \mathrm{~S} 1$ ), spanning the peak in annual biomass. The 12 imaged samples from Tatoosh Island include 4 106 pairs ( $\mathrm{n}=8$ samples) from both the base (near the meristematic tissue) and the tip (older tissue) 107 of the same kelp frond over the time series, and an additional 4 samples from the tip of different 108 kelp blades in June and July (Table S1). Samples were processed for 16S rRNA gene sequencing 109 as previously reported (Weigel and Pfister 2019); additional samples, taken in parallel, were 110 collected and preserved in 95\% ethanol for CLASI-FISH.

111 Characterizing the microbiome of $N$. luetkeana with 16S rRNA gene sequencing revealed 112 a community that was diverse but composed of the same major taxa at all sampled time points 113 and both locations (Fig. 1, Weigel and Pfister, 2019). The most abundant genus-level taxon was 114 Granulosicoccus (Gammaproteobacteria), which accounted for close to half of the sequences 115 overall in samples from Tatoosh Island (Fig. 1); other major taxa included Alphaproteobacteria, 116 Bacteroidetes, and Verrucomicrobia. In samples from the declining Squaxin Island kelp 117 population, Alphaproteobacteria were dominant, comprising $>75 \%$ of the microbial community 118 (Fig. 1).

119 In contrast to sequencing, which provides information on community structure at 120 centimeter scales, imaging permits micrometer-scale analysis of microbial spatial organization.

121 To investigate the spatial organization of the kelp microbiota we developed a probe set for 122 CLASI-FISH (Combinatorial Labeling and Spectral Imaging- Fluorescence in situ 123 Hybridization) to enable simultaneous identification and imaging of the major bacterial groups. 124 For comprehensive coverage of bacteria, we used the probes Eub338-I, II, and III (Amann et al. 
125 1990, Daims et al. 1999) using one fluorophore for probe Eub338-I and a different fluorophore 126 to label both Eub338-II and Eub338-III, to differentiate the Verrucomicrobia and Planctomycetes 127 from the rest of the Bacteria. For greater taxonomic resolution within the bacteria identified by 128 Eub338-I, the probe set contained probes specific for the major groups comprising the $N$. 129 luetkeana microbiota: Bacteroidetes, Alphaproteobacteria, and Gammaproteobacteria. For added 130 taxonomic resolution within Gammaproteobacteria we designed two new probes targeting the 131 most abundant genus, Granulosicoccus. Thus, the probe set targeted nested levels of taxonomic 132 identification, with cells identified by combinations of one, two, or three fluorophores (Table 1). 133 We tested probe specificity by applying the set of 7 probes to 5 pure cultures. Each probe 134 hybridized with its target taxa and only faint hybridization was observed with nontarget taxa 135 (Fig. S1 and S2).

For sample preparation we employed two strategies: whole-mount preparation and 137 embedding and sectioning. Whole-mount preparations enable imaging of a large surface area of 138 kelp blade but have the disadvantage that layers of the kelp tissue tend to separate over the 139 course of the hybridization and washing steps. We found that coating the tissue with a layer of 140 agarose at the beginning of the experiment helped the sample to remain intact during subsequent 141 manipulations (see Methods). An alternative preparation procedure, in which the sample was 142 embedded in methacrylate resin followed by sectioning and application of probes to the sections 143 mounted on a slide, preserved spatial organization by immobilizing the sample in resin and 144 permitted imaging of thin cross-sections through the kelp blade.

145 Imaging of such cross-sections of kelp embedded in methacrylate enabled us to visualize 146 the overall relationship of the microbiota to the underlying kelp tissue (Fig. 2A). The kelp tissue 147 itself is visible in a transmitted-light image as a series of large irregularly shaped chambers 148 (sieve tubes), with a row of oblong photosynthetic cells along both the upper and the lower 149 surface of the blade (Fig. 2A). The microbes are located primarily in a dense layer several 150 micrometers thick on the exterior of both the upper and lower surface. Imaging at a 151 magnification sufficient to visualize individual bacterial cells shows each taxon as single cells or 152 small clumps, often immediately adjacent to cells of different taxonomic identification (Fig. 2A, 153 insets i-iii). In addition to the surface layer, some bacteria are present in the interior of the blade; 154 a subset of the community consisting largely of Bacteroidetes rods can be seen within the kelp 155 tissue immediately beneath the surface layer (Fig. 2Ai), and a small cluster of mixed composition 
156 is visible near the center of the image (Fig. 2Aii). Thus, a variety of modes of interaction

157 between microbiota and host can be visualized in cross-sectional view.

158 By contrast, placing a whole-mount of a kelp blade flat on a microscope slide permitted 159 imaging of a vertical series (or z-stack) of images from the surface of the kelp blade through the 160 biofilm (Fig. 2B). This whole-mount imaging reveals the relationship of microbial cells to one 161 another and the changing composition of the community as a function of distance from the kelp 162 blade. Moving up from the plane in which the kelp photosynthetic cells are visible (Fig. 2B), 163 serial optical sections show first a largely fluorescence-free region a few micrometers thick and 164 then dense colonization by a mixed microbial community. At approximately 3 to $6 \mu \mathrm{m}$ from the 165 surface of the blade, clusters of Granulosicoccus cells are prominent and diatoms are visible 166 (Fig. 2B). In the region approximately 8 to $12 \mu \mathrm{m}$ from the blade surface, filaments are a more 167 prominent part of the community. Non-filamentous cells of Alphaproteobacteria, Bacteroidetes 168 and Verrucomicrobia or Planctomycetes are present throughout the biofilm. The whole-mount 169 images, like the cross-sections, show that cells of diverse taxa are directly adjacent to one another in the kelp surface biofilm.

171 In perfectly flat whole-mount images one sees either the algal surface or the microbiota

172 but not both unless the microbiota has invaded into the tissue. In many whole-mount images, 173 however, the algal surface and the overlying microbiota can be seen simultaneously because the 174 sample is tilted relative to the plane of imaging, such that the confocal microscope image is an

175 optical section through the sample at an oblique angle and a single plane of focus captures both 176 the kelp blade and the microbial community. In the example in Fig. 2C, kelp cells are visible as

177 large $(\sim 5 \mu \mathrm{m} \times 10 \mu \mathrm{m})$ oblongs at the right; Bacteroidetes spp. are intercalated between the kelp 178 cells. In the center of the image a scattering of taxonomically mixed bacteria are located on or 179 between the kelp cells, while at the left-hand side of the image the full microbial community is 180 visible. As most whole-mount preparations are not entirely flat, many images represent to one 181 degree or another an oblique-angle view of the material.

182 Bacteria on kelp blades form mixed epiphytic communities whose abundance is dependent 183 on the age of the underlying tissue

184 Due to the high growth rate of the kelp thallus, producing multiple centimeters of new 185 tissue in a single day (Weigel and Pfister 2019), it is possible to study how spatial structure and 
186 diversity of the microbial community differ between newly produced tissue vs. tissue that is weeks to months old. Although the microbial community on older tissue contains more microdiversity, the composition and relative abundances of major taxa are broadly consistent across young and old tissues (Fig. 1, Weigel and Pfister 2019). However, imaging showed a

190 higher density of colonization at the tip of the blade, which is months old, compared to the base,

191 where newly produced tissue is only days old (Fig. 3). At the tip (Fig. 3 A-C) cells form a

192 confluent biofilm, whereas at the base only scattered cells are visible (Fig. 3 D-F). This pattern is

193 observed in samples collected throughout the summer (Fig 3).

194 Typical images of the tip community (Fig. 4) show that bacteria at the tip of blades are

195 mixed at micron scales. Granulosicoccus, the most abundant genus in the 16S rRNA gene 196 sequencing, formed patches or clusters up to $15 \mu \mathrm{m}$ in diameter in some samples (Fig. 4A); close 197 inspection reveals cells of other taxa nestled within the clusters (Fig. 4A). Alphaproteobacteria,

198 Bacteroidetes rods, Verrucomicrobia and Planctomycetes did not form large clusters but instead 199 are intermixed in the biofilm. In whole-mount preparations, Bacteroidetes filaments lie on top of 200 the other bacteria (Fig. 4A, B), suggesting that they are located in a different level of the biofilm 201 and become flattened onto the sample during the FISH and mounting procedure. This 202 observation is reinforced by cross-section images, which show a biofilm typically 3 to $5 \mu \mathrm{m}$ 203 thick, with filaments projecting approximately $10 \mu \mathrm{m}$ from the biofilm (Fig. 4C).

204 In addition to a dense bacterial biofilm, colonies of diatoms were observed, mainly in 205 samples collected in June and July 2017 (Fig.4A; Fig. 5). In a cross-sectional image, it was 206 apparent that diatoms were embedded within the biofilm and a layer of bacteria is observed 207 between the diatoms and the kelp tissue (Fig. 5C, D), suggesting that the diatoms colonized the 208 host after the bacteria. No specific association between diatoms and particular bacterial taxa was 209 observed.

\section{Endophytic bacteria and direct interactions with the blade surface}

211 Endophytic bacteria have been reported in macroalgae (Hollants et al. 2011) but have not 212 previously been imaged with probes that could distinguish multiple taxa. In addition to the 213 superficial biofilm, we detected bacteria inside kelp tissue by imaging cross-sections (Fig. 6). 214 Bacteroidetes rods and, less abundantly, other members of the community were observed 215 colonizing intercellular spaces of the outermost layer of kelp cells in samples from July (Fig. 2A, 
216 2C, Fig. 6). These endophytic Bacteroidetes were located adjacent to kelp cells that may be

217 especially metabolically active given their strong autofluorescence. Microbes occasionally

218 colonized the surface layer of cells directly (Fig. 6B), but in contrast to the Bacteroidetes-rich

219 invasion into highly autofluorescent regions, no obvious preference for any underlying

220 morphology of the kelp was detected. We also observed the microbial community forming small

221 clusters on the interior of the frond (Fig. 2Aii) or forming a strand running through the kelp inner

222 tissue (Fig. 6C, D).

\section{Unipolar labeling of adherent Alphaproteobacteria with wheat germ agglutinin}

224 Wheat germ agglutinin (WGA) is a lectin that binds to $\mathrm{N}$-acetylglucosamine and $\mathrm{N}$ acetylmuramic acid residues that can be present both in bacterial cell walls and in host mucus secretions. We stained samples with fluorophore-labeled WGA and observed staining in spots on the kelp tissue itself, in cells hybridizing with the Granulosicoccus probe, and most intriguingly, on cells hybridizing with the Alphaproteobacteria probe that reacted asymmetrically with the WGA, showing fluorescence at only one end of the cell (Fig. 7). This pattern was observed across multiple kelp collected in different months and sites (Fig. 7A, B) including the declining population of kelp from Squaxin Island (Fig. 8D, E). In cross-section images the exopolysaccharides were present at the end of the cell that was in contact with the kelp surface

233 (Fig. 7C) suggesting a potential role of the WGA-stained structure in adhesion of the microbe to 234 the kelp.

In addition to the samples collected on the outer Pacific Ocean site of Tatoosh Island, we imaged the microbial biofilm of kelp collected at Squaxin Island, located in Southern Puget Sound. Although the same major taxa are present on $N$. luetkeana from both collection sites, their relative abundances differed: Alphaproteobacteria accounted for the bulk $(\sim 75 \%)$ of the microbial community in $16 \mathrm{~S}$ rRNA gene sequences from Squaxin samples (Fig. 1). Imaging revealed dramatically lower density of microbes in Squaxin samples (Fig. 8) compared to the tip

242 of Tatoosh blades and similar densities to the Tatoosh base samples. Interestingly, kelp blades at 243 Squaxin Island were sampled during the same week as the late June Tatoosh kelp (Table S1, 244 June 21 vs. June 25), yet the Tatoosh kelp (Fig. 4A) have a much greater density of bacterial 
cells than the Squaxin Island kelp. While it is difficult to infer an exact comparison, given that the Squaxin kelp blades were sampled from the middle of the blade while the Tatoosh kelp communities were sampled at the base and tip of the blade, the estimated age of sampled tissue from Squaxin kelp was approximately 2 months, similar to that of the tissue collected from the tip of the kelp blade on Tatoosh Island (Table S1). Thus, samples collected at the base of the Tatoosh blades that were less than 1 week old had similar microbial densities to these 2-monthold biofilms on kelp from Squaxin Island.

\section{Micron-scale spatial arrangement}

Using image analysis with daime (Daims et al. 2006), we counted a mean of 4025 Granulosicoccus cells and 2445 Verrucomicrobia-Planctomycetes cells per image on 8 Nereocystis individuals (Table 2). Overall densities of Granulosicoccus averaged 89,056 cells per $\mathrm{mm}^{2}$ and as high as 269,049; the Verrucomicrobia-Planctomycetes probe identified an average of 54,100 cells per $\mathrm{mm}^{2}$, with a maximum of 94,530. These numbers are likely underestimates of the total colonization of the kelp surface, as they represent only the cells visible in a single focal plane. Cell size was comparable with the VerrucomicrobiaPlanctomycetes measuring 0.42 and Granulosicoccus measuring $0.47 \mu \mathrm{m}$ in diameter across all 8 individuals (Table 2).

Linear dipole analysis can be used to calculate the spatial correlation between two taxa, or between a taxon and itself, over a range of distances. We carried out linear dipole analysis in daime to analyze within-taxon and between taxon associations for the genus Granulosicoccus and the Verrucomicrobia-Planctomycetes (hereafter referred to as simply Verrucomicrobia) for each of 8 kelp individuals. Results indicated that both Granulosicoccus and Verrucomicrobia cells were positively autocorrelated spatially at distances less than 10 um (Table 2, Fig. S3). When we quantified spatial covariance for both taxa, their co-occurrence was observed at distances less than $5 \mu \mathrm{m}$ and peaked at $1.61 \mu \mathrm{m}$ (Table 2, Fig. S3).

While these correlations may reflect a tendency of these specific cell types to localize close to one another, they could also result from overall patchiness in colonization of the frond, or from imaging or preparation artifacts (e.g. from compression of the samples between slide and coverslip, or conversely from the sample being not entirely flat in the plane of focus). 


\section{Discussion}

275

276

277

278

279

280

281

282

283

284

285

286

287

288

289

290

291

292

293

294

295

296

\section{Comparison of the Nereocystis microbiota to other microbiomes}

CLASI-FISH reveals the microbiota of Nereocystis to be dense and complex. The bacterial community growing on or within macroalgal fronds has been visualized by other investigators using FISH with one or a few taxa (Tujula et al. 2006, 2010; Bengtsson and Ovreas 2010), showing a biofilm composed of cocci and filaments and highlighting the distribution of individual taxa. The benefit of CLASI-FISH is the ability to identify the major groups simultaneously and assess their relative distribution and potential for direct spatial interaction. The probe set we employed provides rather coarse resolution, with most of the targeted taxa visualized at the phylum or class level; nonetheless we visualized micron-scale interaction among these diverse taxa and our results lay out a framework that can be furthered by future experiments using more complex and specific probe sets.

The microbiota visualized here is notable for its high density but moderate thickness. In the most densely colonized samples, our images show a confluent biofilm several cells thick. With a typical microbial diameter of $0.5 \mu \mathrm{m}$, this confluent biofilm corresponds to a density of $10^{8}-10^{9}$ cells $/ \mathrm{cm}^{2}$, comparable to the density of $10^{7}-10^{8}$ cells $/ \mathrm{cm}^{2}$ measured for the brown alga Fucus vesiculosus (Stratil et al. 2013). Other marine organisms have a lower surface colonization density; for example, the density of microbes in coral mucus is estimated at only $10^{5}-10^{6}$ per $\mathrm{cm}^{3}$ (Garren and Azam 2010; Glasl et al. 2016), on the same order of magnitude as the density in surrounding seawater. Compared to the communities that grow on the human tongue and teeth, the kelp microbiota has similar complexity, but its thickness, in the range of 10 microns, is limited compared to the potentially hundreds of microns in thickness achieved by the microbiota of the human mouth (Zijnge et al. 2010, Mark Welch et al. 2016, Wilbert et al. 2019 in press).

\section{Functional implications of the kelp microbiota}

The functional importance of the dense microbial layer that we have revealed through CLASI-FISH is relatively unknown, but the position of the microbial layer at the interface between the host tissue and the surrounding water column suggests the possibility for important consequences for biofouling, access of the host organism to light and nutrients, and metabolic exchange. Mucus production by kelps may play a critical role in providing structure for surface- 
associated microbes. Potential benefits of these microbes to the host may include generation of antibacterial compounds that protect the host against fouling and pathogens (Rao et al. 2007; Egan et al. 2013, Michelou et al. 2013, Tebben et al. 2014, Lee et al. 2016) or competitors (Barott and Rohwer 2012). In turn, microbes likely benefit from a predictable source of dissolved organic matter and a persistent substrate for colonization. Possible functional interactions between macroalgae and their epibionts, both detrimental and potentially beneficial, have been the subject of several recent reviews (Wahl et al. 2012; Ramanan et al. 2016; Singh and Reddy 2016; Florez et al. 2017).

The limited thickness of the microbial biofilm that we imaged raises the question of whether this biofilm is thin enough so as to permit unattenuated light penetration to the kelp itself and raises the question of what mechanisms may exist by which the thickness of the biofilm may be limited. Is there a dynamic process of biofilm loss via host shedding of the mucous coating to which the biofilm may adhere, followed by re-growth of the biofilm? Alternatively, is biofilm thickness limited by the intrinsic rate of growth of the microbes or their accretion from the water column, or by grazing of the biofilm by micro- or macro-invertebrates? Interestingly, the Granulosicoccus sp. genome contains 30 flagella genes (Kang et al. 2018), leading to the possibility that this bacterium is motile, which would provide a mechanism for its early colonization of the kelp tissue from the seawater as well as its high abundances on the kelp surface.

Imaging reveals close association, at micrometer scales, of different microbial taxa with one another and with the host, a spatial organization that creates the conditions necessary for metabolic exchange among microbes (Seth and Taga 2014) and between host and microbiota. While recent studies have described microbial communities in association with kelp through genomics (Michelou et al. 2013, Lemay et al. 2018, Qiu et al. 2019), the metabolic role of the microbes relative to the host has yet to be clarified. Nutrient exchanges between host and microbes are functionally significant in phytoplankton (e.g. Amin et al. 2015). Nereocystis at Tatoosh Island release $\sim 20 \%$ of fixed carbon into the surrounding seawater as dissolved organic carbon (DOC) (Weigel and Pfister, in review), a quantity consistent with DOC release estimates for other kelp species (Abdullah \& Frederiksen 2004, Reed et al. 2015). By living on the kelp surface, biofilm microbes are presented with a consistent and labile metabolic resource, in addition to the structural kelp polymers that kelp microbes can degrade (Bengtsson et al. 2011). 
334 The release of carbohydrate exudates likely favors heterotrophic microbial metabolisms, and the

335 Granulosicoccus sp. sequence variant in this study shares $97 \%$ sequence identity to

336 Granulosicoccus antarcticus (Lee at al. 2007), which is a heterotrophic microbe that contains

337 urease and both nitrate and nitrite reductase genes (Kang et al. 2018). As a heterotroph,

338 Granulosicoccus sp. likely takes advantage of the abundant DOC, while nitrogen transformation

339 genes suggest a potential for nitrogen metabolisms that may impact the host kelp. Likewise,

340 studies of microbial nutrient transformation in near-shore waters of Tatoosh Island showed that

341 these microbial nitrogen metabolisms were strongest in association with the surfaces of a red

342 alga, Prionitis sternbergii, rather than in seawater or associated with inert substrates (Pfister and

343 Altabet 2019). This finding suggests that epibiont communities on algae are enriched for

344 microbes carrying out ammonium oxidation and nitrate reduction, both of which might serve to

345 retain and recycle dissolved inorganic nitrogen (DIN) near the surface of the alga.

346 Low density of microbiota and high fraction of Alphaproteobacteria on declining population of kelp

348 Shifts in microbial composition between healthy and stressed macroalgae have been 349 reported (Marzinelli et al. 2015), but the low density of bacteria on the kelp from Squaxin Island 350 was unexpected, as we had initially assumed that a population in decline would be more likely to 351 be overrun with microbes than nearly devoid of them. The majority of the bacterial epibionts at 352 Squaxin were shown by both sequencing and imaging to be Alphaproteobacteria, most likely 353 represented by the single highly-abundant ASV in the sequencing data identified as a member of 354 the Hyphomonadaceae. Alphaproteobacteria from the family Rhizobiales produce unipolar 355 adhesins which are essential for cell-cell adhesion, biofilm formation and effective root 356 colonization (Fritts et al. 2017; Williams et al. 2008). The exopolysaccharide N357 acetylglucosamine, synthesized by bacterial cells, plays an important role in biofilm formation in 358 Staphylococcus aureus (Izano et al. 2008, Lin et al. 2015) and Escherichia coli (Wang et al. 359 2004). Interestingly, the consistent presence of $\mathrm{N}$-acetylglucosamine or $\mathrm{N}$-acetylmuramic acid 360 residues at one end of Alphaproteobacteria cells suggests that it may be involved in cell 361 adhesion to the kelp mucous layer. The high relative abundance of Alphaproteobacteria in 362 Squaxin samples, in which the observed bacteria density is low, might be related to a similar 
363 attachment strategy that would allow them to attach to the kelp surface more permanently or

364 more readily than other members of the microbiota.

Materials and Methods

Sample collection and 16S rRNA gene sequencing

Photosynthetic blade tissues of Nereocystis luetkeana were sampled at five time points spaced roughly 2 weeks apart (11 June - 22 August 2017) on Tatoosh Island, Washington in the United States $\left(48^{\circ} 23^{\prime} 37.0^{\prime \prime} \mathrm{N} 124^{\circ} 44^{\prime} 06.5^{\prime \prime} \mathrm{W}\right)$. At each time point, two tissue samples $\left(2 \times 1 \mathrm{~cm}^{2}\right)$ were collected from a single blade - one at the basal meristem, roughly $2 \mathrm{~cm}$ from where the blade connects to the stipe, to capture recently produced tissue ( $\sim 24$ to 48 hours old) and another near the apical end of the blade tip to sample older tissue (weeks to months old). Samples were collected from different kelp individuals at each date, and $n=2$ or 3 samples from each date were selected for imaging. Total blade length and linear blade growth rates were measured to approximate the age of tissues sampled (Weigel and Pfister 2019). Kelp blade tissues samples were also collected from Squaxin Island, in the Southern Puget Sound $\left(47^{\circ} 10^{\prime} 38.7^{\prime \prime N}\right.$ $\left.122^{\circ} 54^{\prime} 42.2^{\prime \prime} \mathrm{W}\right)$ on 21 June 2017. At this site, kelp tissue samples were collected from the middle of the kelp blade, and $n=3$ samples were selected for imaging. Kelp blade tissues for CLASI-FISH and 16S rRNA sequencing were collected together from adjacent locations on the kelp blade. Samples collected for CLASI-FISH were preserved in 95\% ethanol and stored at -

$38120^{\circ} \mathrm{C}$, while samples for $16 \mathrm{~S}$ rRNA had no preservatives and were temporarily frozen at $-20^{\circ} \mathrm{C}$ 382 until they were shipped to $-80^{\circ} \mathrm{C}$. Details of DNA extraction, 16S rRNA gene sequencing, and sequence analysis are contained in Weigel and Pfister (2019).

\section{Probe design for Granulosicoccus and Probe set validation}

Probes for genus Granulosicoccus were designed based on sequencing results. An

386 alignment of all Granulosicoccus V4 fragment sequences and most abundant ASVs from all the 387 other taxa was performed using Geneious 11.1.3. Alignment was reviewed manually to look for 388 candidate regions for probe design. We selected sequence regions which match all the 389 Granulosicoccus sequences and did not match any of the other taxa. Probe hybridization 390 efficiency was evaluated using mathFISH (Yilmaz et al., 2011). Two probes were designed: 

TCAGCGTCAGTATTGTTCCAGA-3').

393 To validate the probes for specificity, we applied the set of 7 probes simultaneously to 394 pure cultures and hybridized and imaged under the same conditions as kelp samples (Fig. S1).

395 Probes used in this study are listed in Table 1.

\section{Bacterial strains and growth conditions}

Granulosicoccus coccoides DSM 25245 and G. antarcticus DSM 24912 were cultured in Bacto Marine Broth media (DIFCO 2216) (pH 7.5 and 7 for G. coccoides and G. antarcticus, respectively). Cultures were incubated with agitation $(180 \mathrm{rpm})$ at $25^{\circ} \mathrm{C}$. Two- and 7-days cultures were fixed with $2 \%$ PFA on ice for $90 \mathrm{~min}$, washed and transferred to $50 \%$ ethanol. Fixed cells were stored at $-20^{\circ} \mathrm{C}$ until use.

\section{Embedding and sectioning for imaging}

For methacrylate embedding, kelp samples stored in $95 \%$ ethanol at $-20^{\circ} \mathrm{C}$ were placed in $100 \%$ ethanol for $30 \mathrm{~min}$ followed by acetone for 1 hour, infiltrated with Technovit 8100 glycol methacrylate (EMSdiasium.com) infiltration solution $3 \mathrm{~h}$ replacing for fresh solution every hour and followed by a final infiltration overnight at $4^{\circ} \mathrm{C}$. Samples were then transferred to Technovit

4078100 embedding solution and solidified for $12 \mathrm{~h}$ at $4{ }^{\circ} \mathrm{C}$. Blocks were sectioned to $5 \mu \mathrm{m}$ 408 thickness using a Leica microtome (RM2145) and applied to Ultrastick slides (Thermo 409 Scientific). Sections were stored at room temperature until CLASI-FISH was performed.

412 CLASI-FISH microscopy was carried out on a subset of samples analyzed previously by 413 16S rRNA sequencing and reported in Weigel and Pfister (2019).

414 We used two methods to visualize the spatial structure of the kelp microbiota: whole415 mount-agarose preparations and methacrylate sections. When possible, we used pieces of the 416 same kelp sample for both methods. For the whole-mount-agarose method one piece of kelp was 417 placed on a slide and $50 \mu 1$ of $1 \%$ low-melting-point agarose was dropped on it and the sample 
418 allowed to cool on ice for $10 \mathrm{~min}$ before the CLASI-FISH procedure. Methacrylate sections were subject to CLASI-FISH directly on slides.

Hybridization solution [900 mM NaCl, $20 \mathrm{mM}$ Tris, pH 7.5, 0.01\% SDS, 20\% (vol/vol)

421 formamide, each probe at a final concentration of $2 \mu \mathrm{M}$ ] was applied to kelp pieces and

422 incubated at $46{ }^{\circ} \mathrm{C}$ for $2 \mathrm{~h}$ in a chamber humidified with $20 \%$ (vol/vol) formamide. Whole423 mount-agarose preparations were maintained in horizontal position and were washed with $100 \mu \mathrm{l}$ 424 of pre-warmed wash buffer (215 mM NaCl, $20 \mathrm{mM}$ Tris, $\mathrm{pH}$ 7.5, 5mM EDTA) five times at RT 425 followed by three washes with $500 \mu$ of wash buffer at $48^{\circ} \mathrm{C}$ for $5 \mathrm{~min}$ each. The hybridization 426 conditions were the same for methacrylate sections, but washing was carried out by incubating 427 the slides in $50 \mathrm{ml}$ of washing buffer for 15 minutes at $48^{\circ} \mathrm{C}$. Samples were then incubated with 428 wheat germ agglutinin $\left(20 \mu \mathrm{g} \mathrm{ml}^{-1}\right)$ conjugated with Alexa Fluor 680 at room temperature for 30 $429 \mathrm{~min}$ in the dark. Agarose-coated samples were washed with $100 \mu \mathrm{l}$ of sterile cold water three 430 times. Excess agarose was cut off with a disinfected razor. Methacrylate sections were washed 431 by dipping the slide into $50 \mathrm{ml}$ of ice-cold water to remove excess salt. Samples were mounted in 432 ProLong Gold antifade reagent (Invitrogen) with a \#1.5 coverslip and cured overnight in the dark 433 at room temperature before imaging.

\section{Image acquisition and linear unmixing}

Spectral images were acquired using a Carl Zeiss LSM 780 confocal microscope with a

436 Plan-Apochromat 40X, 1.4 N.A. oil immersion objective. Images were captured using simultaneous excitation with 405, 488, 561, and $633 \mathrm{~nm}$ laser lines. Linear unmixing was

438 performed using ZEN Black software (Carl Zeiss) using reference spectra acquired from cultured 439 cells hybridized with Eub338-I probe labeled with one of the 6 fluorophores in the probe set and 440 imaged as above. Unmixed images were assembled and false-colored using FIJI software 441 (Schindelin et al., 2012).

\section{Spatial Analysis of CLASI-FISH images}

We used the software daime (Daims et al. 2006) to analyze the spatial structure and the 444 size of the cells identified with CLASI-FISH on 8 separate Nereocystis individuals ( $\mathrm{n}=2$ to 13 445 images each) collected between 11 Jun to 22 Aug 2017. We imported images that were 212.55 $\mu \mathrm{m}$ on a side for each probe separately as TIFF files, enhanced the contrast manually, and used 
automatic 2D segmentation with the RATS-L thresholding algorithm to select and count cells. Very small objects were interpreted to be noise and were manually removed using the object editor. We quantified spatial distribution using 'scan whole reference space' to a distance of 50 $\mu \mathrm{m}$ and recorded the correlation at every $0.15 \mu \mathrm{m}$ using the $2 \mathrm{D}$ linear dipole algorithm.

\section{Acknowledgements}

Funding was provided by NSF award 1650141 (to JMW) and the NOAA-COCA program through NA16OAR431055 (to CAP). BLW was supported by a National Geographic Society Early Career Grant, a Phycological Society of America Grants-in-Aid of Research, a Department of Education GAANN fellowship, and a travel award from the Committee on Evolutionary Biology at the University of Chicago. LJ was supported in part by NSF REU award 1659604, "Biological Discovery in Woods Hole at the Marine Biological Laboratory." We thank the Makah Tribal Nation for access to Tatoosh Island, and H. Berry, T. Mumford and the Washington DNR for boat logistics at Squaxin Island. T. Bowyer, K. Miranda, A.M. Wootton, J.B. Wootton, and J.T. Wootton all helped in the field. We thank Tracy Mincer, Linda AmaralZettler and Erik Zettler for providing microbial cultures for probe testing.

The funders had no role in study design, data collection and interpretation, or the decision to submit the work for publication.

\section{References}

1. Abdullah, M. I., \& Fredriksen, S. (2004). Production, respiration and exudation of dissolved organic matter by the kelp Laminaria hyperborea along the west coast of Norway. Journal of the Marine Biological Association of the UK, 84(5), 887-894. doi: $10.1017 / \mathrm{S} 002531540401015 \mathrm{Xh}$

2. Amann, R. I., Binder, B. J., Olson, R. J., Chisholm, S. W., Devereux, R., \& Stahl, D. A. (1990). Combination of 16S rRNA-targeted oligonucleotide probes with flow cytometry for analyzing mixed microbial populations. Applied and environmental microbiology, 56(6), $1919-1925$.

3. Amin, S. A., Hmelo, L. R., van Tol, H. M., Durham, B. P., Carlson, L. T., Heal, K. R., Morales, R. L., Berthiaume, C. T., Parker, M. S., Djunaedi, B., Ingalls, A. E., Parsek, M. R., 
Moran, M. A., \& Armbrust, E. V. (2015). Interaction and signalling between a cosmopolitan phytoplankton and associated bacteria. Nature, 522(7554), 98-101. doi:10.1038/nature14488

4. Barott, K. L., \& Rohwer, F. L. (2012). Unseen players shape benthic competition on coral reefs. Trends in microbiology, 20(12), 621-628. doi:10.1016/j.tim.2012.08.004

5. Bengtsson, M. M., \& Øvreås, L. (2010). Planctomycetes dominate biofilms on surfaces of the kelp Laminaria hyperborea. BMC microbiology, 10, 261. doi:10.1186/1471-2180-10-261

6. Bengtsson, M. M., Sjøtun, K., Storesund, J. E., Øvreas, L. (2011). Utilization of kelp-derived carbon sources by kelp surface-associated bacteria. Aquatic Microbial Ecology 62(2), 191199. 10.3354/ame01477

7. Berry, H. D., Mumford, T. F., Christiaen, B., Dowty, P., Calloway, M., Ferrier, L., Grossman, E. E., VanArendonk, N. R., (2020). Long-term changes in kelp forests in an inner basin of the Salish Sea. doi: 10.1101/2020.02.13.947309

8. Chen, M., Parfrey, L. (2018) Incubation with macroalgae induces large shifts in water column microbiota, but minor changes to the epibiota of co-occurring macroalgae. Mol Ecol, 27(8), 1966-1979. doi: 10.1111/mec.14548

9. Cordero O.X., Datta M.S. (2016). Microbial interactions and community assembly at microscales. Curr Opin Microbiol. 31:227-234. doi:10.1016/j.mib.2016.03.015

10. Daims, H., Brühl, A., Amann, R., Schleifer, K. H., \& Wagner, M. (1999). The domainspecific probe EUB338 is insufficient for the detection of all Bacteria: development and evaluation of a more comprehensive probe set. Systematic and applied microbiology, 22(3), 434-444. doi:10.1016/S0723-2020(99)80053-8

11. Daims, H., Lücker, S., \& Wagner, M. (2006). daime, a novel image analysis program for microbial ecology and biofilm research. Environmental microbiology, 8(2), 200-213. doi:10.1111/j.1462-2920.2005.00880.x

12. Dal Co A, Ackermann M, van Vliet S. Metabolic activity affects the response of single cells to a nutrient switch in structured populations. $J$ R Soc Interface. 2019;16(156):20190182. doi:10.1098/rsif.2019.0182

13. Egan, S., Harder, T., Burke, C., Steinberg, P., Kjelleberg, S., \& Thomas, T. (2013). The seaweed holobiont: understanding seaweed-bacteria interactions. FEMS Microbiology Reviews, 37(3), 462-476. doi: 10.1111/1574-6976.12011 
14. Egan, S., Harder, T., Burke, C., Steinberg, P., Kjelleberg, S., \& Thomas, T. (2013). The seaweed holobiont: understanding seaweed-bacteria interactions. FEMS microbiology reviews, 37(3), 462-476. doi:10.1111/1574-6976.12011

15. Florez, J. Z., Camus, C., Hengst, M. B., \& Buschmann, A. H. (2017). A Functional Perspective Analysis of Macroalgae and Epiphytic Bacterial Community Interaction. Frontiers in microbiology, 8, 2561. doi:10.3389/fmicb.2017.02561

16. Fritts, R. K., LaSarre, B., Stoner, A. M., Posto, A. L., \& McKinlay, J. B. (2017). A Rhizobiales-Specific Unipolar Polysaccharide Adhesin Contributes to Rhodopseudomonas palustris Biofilm Formation across Diverse Photoheterotrophic Conditions. Applied and environmental microbiology, 83(4), e03035-16. doi:10.1128/AEM.03035-16

17. Garren, M., \& Azam, F. (2010). New method for counting bacteria associated with coral mucus. Applied and environmental microbiology, 76(18), 6128-6133. doi:10.1128/AEM.01100-10

18. Glasl, B., Herndl, G. J., \& Frade, P. R. (2016). The microbiome of coral surface mucus has a key role in mediating holobiont health and survival upon disturbance. The ISME journal, 10(9), 2280-2292. https://doi.org/10.1038/ismej.2016.9

19. Hollants, J., Leroux, O., Leliaert, F., Decleyre, H., De Clerck, O., \& Willems, A. (2011). Who Is in There? Exploration of Endophytic Bacteria within the Siphonous Green Seaweed Bryopsis (Bryopsidales, Chlorophyta). PLoS ONE, 6(10), e26458. doi: 10.1371/journal.pone.0026458

20. Izano, E. A., Amarante, M. A., Kher, W. B., \& Kaplan, J. B. (2008). Differential roles of poly-N-acetylglucosamine surface polysaccharide and extracellular DNA in Staphylococcus aureus and Staphylococcus epidermidis biofilms. Applied and environmental microbiology, 74(2), 470-476. doi:10.1128/AEM.02073-07

21. Kang, I., Lim, Y., \& Cho, J. C. (2018). Complete genome sequence of Granulosicoccus antarcticus type strain $\mathrm{IMCC} 3135^{\mathrm{T}}$, a marine gammaproteobacterium with a putative dimethylsulfoniopropionate demethylase gene. Marine genomics, 37, 176-181. doi:10.1016/j.margen.2017.11.005

22. Kolenbrander, P. E., Palmer, R. J., Periasamy, S., \& Jakubovics, N. S. (2010). Oral multispecies biofilm development and the key role of cell-cell distance. Nature Reviews Microbiology, 8(7), 471-480. doi: 10.1038/nrmicro2381 
23. Lamy T., Koenigs, C., Holbrook, S.J., Miller, R.J, Stier, A.C., Reed, D.C. (2020) Foundation species promote community stability by increasing diversity in a giant kelp forest. Ecology. 2020;e02987. doi:10.1002/ecy.2987

24. Lee, K., Lee, H. K., Choi, T. H., Kim, K. M., \& Cho, J. C. (2007). Granulosicoccaceae fam. nov., to include Granulosicoccus antarcticus gen. nov., sp. nov., a non-phototrophic, obligately aerobic chemoheterotroph in the order Chromatiales, isolated from Antarctic seawater. Journal of microbiology and biotechnology, 17(9), 1483-1490.

25. Lee, S. T. M., Davy, S. K., Tang, S.-L., \& Kench, P. S. (2016). Mucus sugar content shapes the bacterial community structure in thermally stressed Acropora muricata. Frontiers in Microbiology, 7. doi: 10.3389/fmicb.2016.00371

26. Lemay, M. A., Martone, P. T., Keeling, P. J., Burt, J. M., Krumhansl, K. A., Sanders, R. D., \& Wegener Parfrey, L. (2018). Sympatric kelp species share a large portion of their surface bacterial communities: Kelp-associated bacterial diversity. Environmental Microbiology, 20(2), 658-670. doi: 10.1111/1462-2920.13993

27. Lin, J. D., Lemay, M. A., \& Parfrey, L. W. (2018). Diverse bacteria utilize alginate within the microbiome of the Giant Kelp Macrocystis pyrifera. Frontiers in Microbiology, 9. doi: 10.3389/fmicb.2018.01914

28. Lin, M. H., Shu, J. C., Lin, L. P., Chong, K. Y., Cheng, Y. W., Du, J. F., \& Liu, S. T. (2015).

29. Manz W, Amann R, Ludwig W, Wagner M, Schleifer KH. 1992. Phylogenetic Elucidating the crucial role of poly $\mathrm{N}$-acetylglucosamine from Staphylococcus aureus in cellular adhesion and pathogenesis. PloS one, 10(4), e0124216. oligodeoxynucleotide probes for the major subclasses of Proteobacteria: problems and solutions. Systematic and Applied Micro- biology 15:593-600. doi:10.1016/S07232020(11)80121-9.

30. Mark Welch, J. L., Rossetti, B. J., Rieken, C. W., Dewhirst, F. E., \& Borisy, G. G. (2016). Biogeography of a human oral microbiome at the micron scale. Proceedings of the National Academy of Sciences of the United States of America,113(6), E791-E800. doi:10.1073/pnas.1522149113

31. Martin, M., Barbeyron, T., Martin, R., Portetelle, D., Michel, G., \& Vandenbol, M. (2015). The Cultivable Surface Microbiota of the Brown Alga Ascophyllum nodosum is Enriched in 
Macroalgal-Polysaccharide-Degrading Bacteria. Frontiers in Microbiology, 6 . doi: $10.3389 /$ fmicb.2015.01487

32. Marzinelli, E. M., Campbell, A. H., Zozaya Valdes, E., Vergés, A., Nielsen, S., Wernberg, T., de Bettignies, T., Bennett, S., Caporaso, J. G., Thomas, T., \& Steinberg, P. D. (2015). Continental-scale variation in seaweed host-associated bacterial communities is a function of host condition, not geography. Environmental microbiology, 17(10), 4078-4088. doi:10.1111/1462-2920.12972

33. Michelou, V. K., Caporaso, J. G., Knight, R., \& Palumbi, S. R. (2013). The Ecology of microbial communities associated with Macrocystis pyrifera. PLoS ONE, 8(6), e67480. doi: 10.1371/journal.pone.0067480

34. Minich, J. J., Morris, M. M., Brown, M., Doane, M., Edwards, M. S., Michael, T. P., \& Dinsdale, E. A. (2018). Elevated temperature drives kelp microbiome dysbiosis, while elevated carbon dioxide induces water microbiome disruption. PLOS ONE, 13(2), e0192772. doi: 10.1371/journal.pone.0192772

35. Neef, A. (1997). Anwendung der in situ-Einzelzell- Identifizierung von Bakterien zur Populations analyse in komplexen mikrobiellen Biozönosen. University of Munich, Munich, Germany.

36. Pfister, C. A., \& Altabet, M. A. (2019). Enhanced microbial nitrogen transformations in association with macrobiota from the rocky intertidal. Biogeosciences, 16(2), 193-206. doi: $10.5194 /$ bg-16-193-2019

37. Pfister, C. A., Berry, H. D., \& Mumford, T. (2017). The dynamics of Kelp Forests in the Northeast Pacific Ocean and the relationship with environmental drivers. Journal of Ecology. doi: $10.1111 / 1365-2745.12908$

38. Pfister, C.A., Altabet, M.A., Weigel, B.L. (2019). Kelp beds and their local effects on seawater chemistry, productivity, and microbial communities. Ecology,100(10):e02798. doi:10.1002/ecy.2798

39. Qiu, Z., Coleman, M. A., Provost, E., Campbell, A. H., Kelaher, B. P., Dalton, S. J., Thomas, T., Steinberg, P. D., \& Marzinelli, E. M. (2019). Future climate change is predicted to affect the microbiome and condition of habitat-forming kelp. Proceedings. Biological sciences, 286(1896), 20181887. doi:10.1098/rspb.2018.1887 
40. Ramanan, R., Kim, B. H., Cho, D. H., Oh, H. M., \& Kim, H. S. (2016). Algae-bacteria interactions: Evolution, ecology and emerging applications. Biotechnology advances, 34(1), 14-29. doi:10.1016/j.biotechadv.2015.12.003

41. Rao, D., Webb, J. S., Holmström, C., Case, R., Low, A., Steinberg, P., \& Kjelleberg, S. (2007). Low densities of epiphytic bacteria from the marine alga Ulva australis inhibit settlement of fouling organisms. Applied and environmental microbiology, 73(24), 78447852. doi:10.1128/AEM.01543-07

42. Reed, D. C., Carlson, C. A., Halewood, E. R., Nelson, J. C., Harrer, S. L., Rassweiler, A., \& Miller, R. J. (2015). Patterns and controls of reef-scale production of dissolved organic carbon by giant kelp Macrocystis pyrifera: DOC production by giant kelp. Limnology and Oceanography, 60(6), 1996-2008. doi: 10.1002/lno.10154

43. Schindelin, J., Arganda-Carreras, I., Frise, E., Kaynig, V., Longair, M., Pietzsch, T., Preibisch, S., Rueden, C., Saalfeld, S., Schmid, B., Tinevez, J. Y., White, D. J., Hartenstein, V., Eliceiri, K., Tomancak, P., \& Cardona, A. (2012). Fiji: an open-source platform for biological-image analysis. Nature methods, 9(7), 676-682. doi:10.1038/nmeth.2019

44. Schlundt, C., Mark Welch, J. L., Knochel, A. M., Zettler, E. R., \& Amaral-Zettler, L. A. (2019). Spatial structure in the "Plastisphere": Molecular resources for imaging microscopic communities on plastic marine debris. Molecular ecology resources, 10.1111/17550998.13119. https://doi.org/10.1111/1755-0998.13119

45. Seth, E. C., \& Taga, M. E. (2014). Nutrient cross-feeding in the microbial world. Frontiers in microbiology, 5, 350. doi:10.3389/fmicb.2014.00350

46. Singh, R. P., \& Reddy, C. R. (2016). Unraveling the Functions of the Macroalgal Microbiome. Frontiers in microbiology, 6, 1488. doi:10.3389/fmicb.2015.01488

47. Stratil, S. B., Neulinger, S. C., Knecht, H., Friedrichs, A. K., \& Wahl, M. (2013). Temperature-driven shifts in the epibiotic bacterial community composition of the brown macroalga Fucus vesiculosus. MicrobiologyOpen, 2(2), 338-349. doi:10.1002/mbo3.79

48. Tarquinio, F., Bourgoure, J., Koenders, A., Laverock, B., Säwström, C., \& Hyndes, G. A. (2018). Microorganisms facilitate uptake of dissolved organic nitrogen by seagrass leaves. The ISME Journal. doi: 10.1038/s41396-018-0218-6 
49. Tebben, J., Motti, C., Tapiolas, D., Thomas-Hall, P., \& Harder, T. (2014). A coralline algalassociated bacterium, pseudoalteromonas strain J010, yields five new korormicins and a bromopyrrole. Marine drugs, 12(5), 2802-2815. doi: 10.3390/md12052802

50. Tujula, N. A., Crocetti, G. R., Burke, C., Thomas, T., Holmström, C., \& Kjelleberg, S. (2010). Variability and abundance of the epiphytic bacterial community associated with a green marine Ulvacean alga. The ISME journal, 4(2), 301-311. doi:10.1038/ismej.2009.107

51. Tujula, N. A., Holmström, C., Mussmann, M., Amann, R., Kjelleberg, S., \& Crocetti, G. R. (2006). A CARD-FISH protocol for the identification and enumeration of epiphytic bacteria on marine algae. Journal of microbiological methods, 65(3), 604-607. doi:10.1016/j.mimet.2005.09.006

52. Valm, A. M., Mark Welch, J. L., \& Borisy, G. G. (2012). CLASI-FISH: principles of combinatorial labeling and spectral imaging. Systematic and applied microbiology, 35(8), 496-502. doi: 10.1016/j.syapm.2012.03.004

53. Valm, A. M., Mark Welch, J. L., Rieken, C. W., Hasegawa, Y., Sogin, M. L., Oldenbourg, R., Dewhirst, F. E., \& Borisy, G. G. (2011). Systems-level analysis of microbial community organization through combinatorial labeling and spectral imaging. Proceedings of the National Academy of Sciences of the United States of America, 108(10), 4152-4157. doi: 10.1073/pnas. 1101134108

54. Wahl, M., Goecke, F., Labes, A., Dobretsov, S., \& Weinberger, F. (2012). The second skin: ecological role of epibiotic biofilms on marine organisms. Frontiers in microbiology, 3, 292. doi:10.3389/fmicb.2012.00292

55. Wang, X., Preston, J. F., 3rd, \& Romeo, T. (2004). The pgaABCD locus of Escherichia coli promotes the synthesis of a polysaccharide adhesin required for biofilm formation. Journal of bacteriology, 186(9), 2724-2734. doi:10.1128/jb.186.9.2724-2734.2004

56. Weigel BL, Pfister CA. (2019). Successional Dynamics and Seascape-Level Patterns of Microbial Communities on the Canopy-Forming Kelps Nereocystis luetkeana and Macrocystis pyrifera. Front Microbiol. 10:346. doi:10.3389/fmicb.2019.00346

57. Wilbert, S.A., Mark Welch, J. L, Borisy, G. G. (2019). Spatial Ecology of the Human Tongue Dorsum Microbiome. Cell Host \& Microbe. doi: 10.2139/ssrn.3438369

58. Williams, A., Wilkinson, A., Krehenbrink, M., Russo, D. M., Zorreguieta, A., \& Downie, J. A. (2008). Glucomannan-mediated attachment of Rhizobium leguminosarum to pea root 
657 hairs is required for competitive nodule infection. Journal of bacteriology, 190(13), 4706-

658 4715. doi: $10.1128 / \mathrm{JB} .01694-07$

659 59. Wilmers, C.C., Estes, J.A., Edwards, M., Laidre, K. L., Konar, B. (2012). Do trophic 660 cascades affect the storage and flux of atmospheric carbon? An analysis of sea otters and $661 \quad$ kelp forests. Front Ecol Environ. 10(8), 409-415. doi:10.1890/110176

662 60. Yilmaz, L. S., Parnerkar, S., \& Noguera, D. R. (2011). mathfish, a web tool that uses 663 thermodynamics-based mathematical models for in silico evaluation of oligonucleotide 664 probes for fluorescence in situ hybrid- ization. Applied and Environmental Microbiology, 665 77(3), 1118-1122. doi:/10.1128/AEM.01733-10

666 61. Zijnge, V., van Leeuwen, M. B., Degener, J. E., Abbas, F., Thurnheer, T., Gmür, R., \& 667 Harmsen, H. J. (2010). Oral biofilm architecture on natural teeth. PloS one, 5(2), e9321. 668 doi:10.1371/journal.pone.0009321 


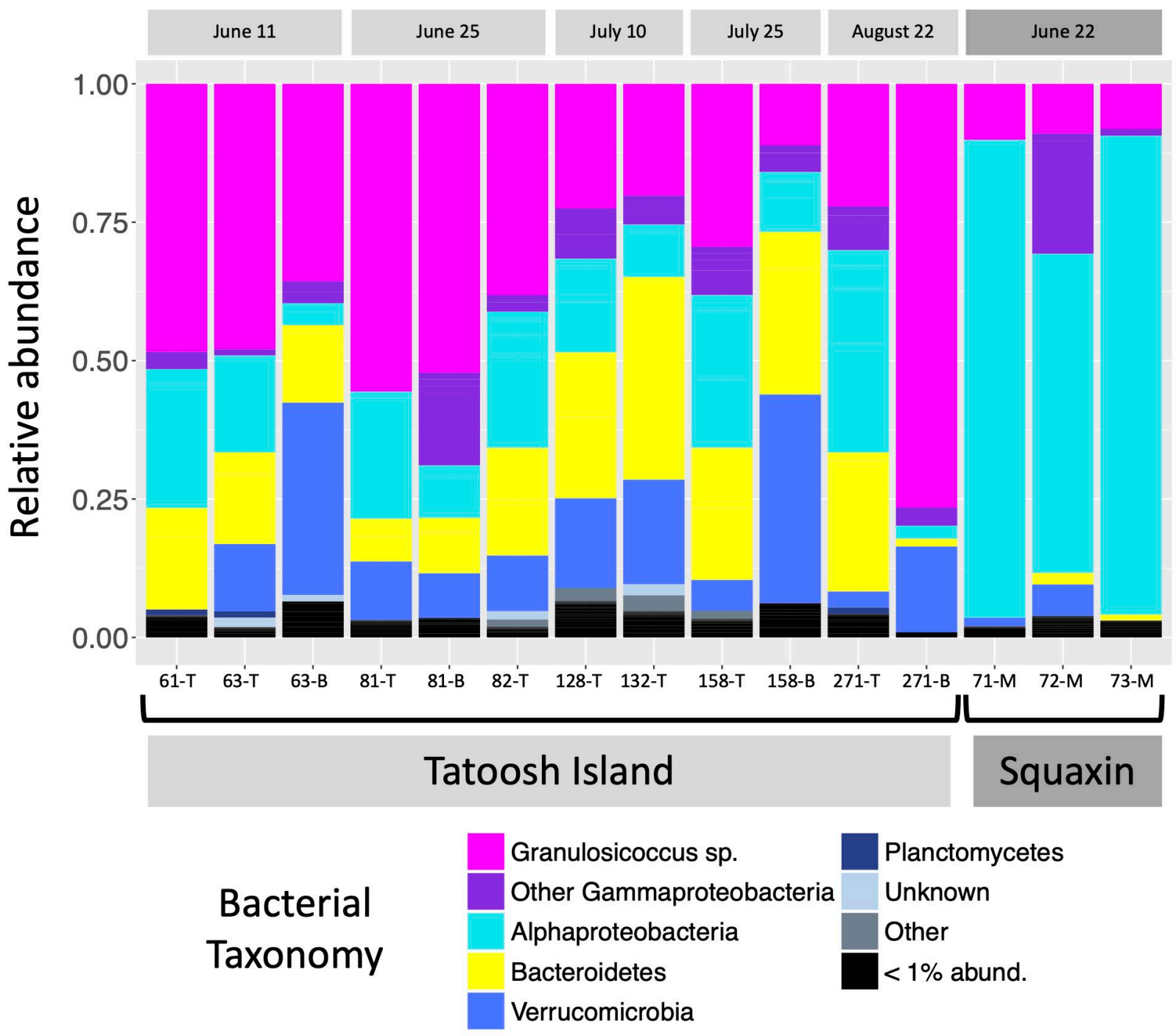

670 Figure 1. Relative abundance of bacterial taxa on the kelp $N$. luetkeana, grouped to show

671 taxa detected by our CLASI-FISH probe set. 16S rRNA gene sequencing showed that

672 bacterial composition is broadly consistent throughout the summer. The most abundant taxa were

673 Verrucomicrobia, Bacteroidetes, Alphaproteobacteria and Gammaproteobacteria. The

674 gammaproteobacterial genus Granulosicoccus was in high abundance in samples from Tatoosh

675 Island. In samples from a declining population at Squaxin Island Granulosicoccus spp. were still

676 present but Alphaproteobacteria were dominant.

677 Collection date is shown at top. Collection site is shown at bottom. Sample number and part of

678 the kelp blade sampled are indicated below each column. $\mathrm{T}=$ tip; $\mathrm{B}=$ base; $\mathrm{M}=$ middle. 

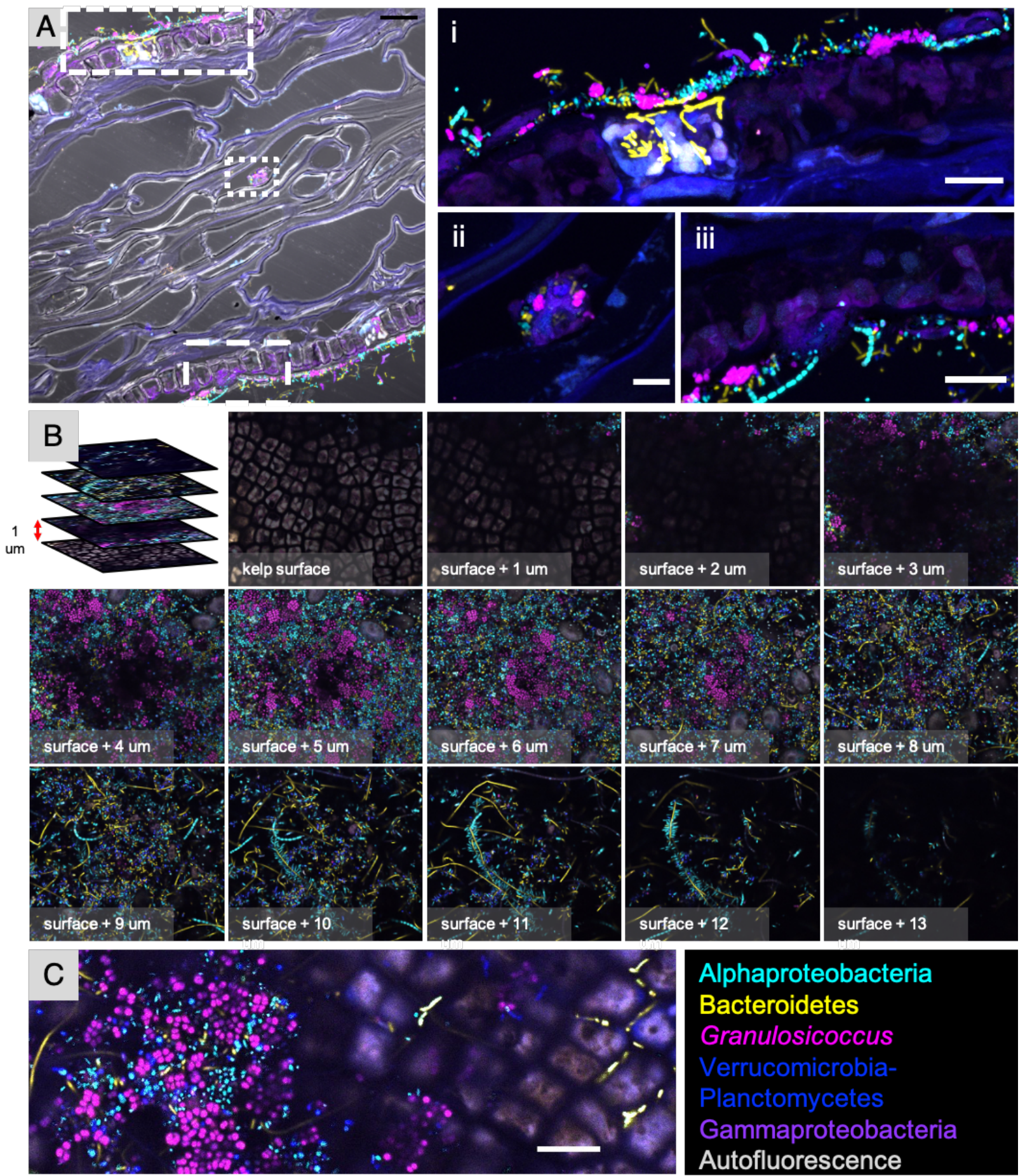

680 views of the biofilm on blades of $\boldsymbol{N}$. luetkeana. Kelp blades were subjected to FISH with a

681 probe set for the 5 major bacterial groups. (A) Cross-section image of a kelp blade embedded in

682 methacrylate. Merge of transmitted light and confocal images shows biofilm on both surfaces 
bioRxiv preprint doi: https://doi.org/10.1101/2020.03.01.972083; this version posted March 3 2020. The copyright holder for this preprin (which was not certified by peer review) is the author/funder, who has granted bioRxiv a license to display the preprint in perpetuity. It is made available under aCC-BY-NC-ND 4.0 International license.

683 and some colonization in center. (i), (ii) and (iii) are enlarged images of the dashed rectangles in 684 panel (A). Bacteroidetes rods present within the autofluorescent region of kelp tissue in panel (i) 685 fluoresce more brightly than rods in the surface biofilm and therefore appear overexposed in the 686 image. (B) Whole-mount preparation imaged as a z-stack; planes 1 micrometer apart in the $\mathrm{z}$ 687 dimension are shown. (C) Oblique optical section showing biofilm at left and kelp surface at 688 right. Bacteroidetes rods are visible between kelp surface cells (right).

689 Scale bar $=20 \mu \mathrm{m}$ in (A); $5 \mu \mathrm{m}$ (i), (ii) and (iii); $10 \mu \mathrm{m}$ in (C).

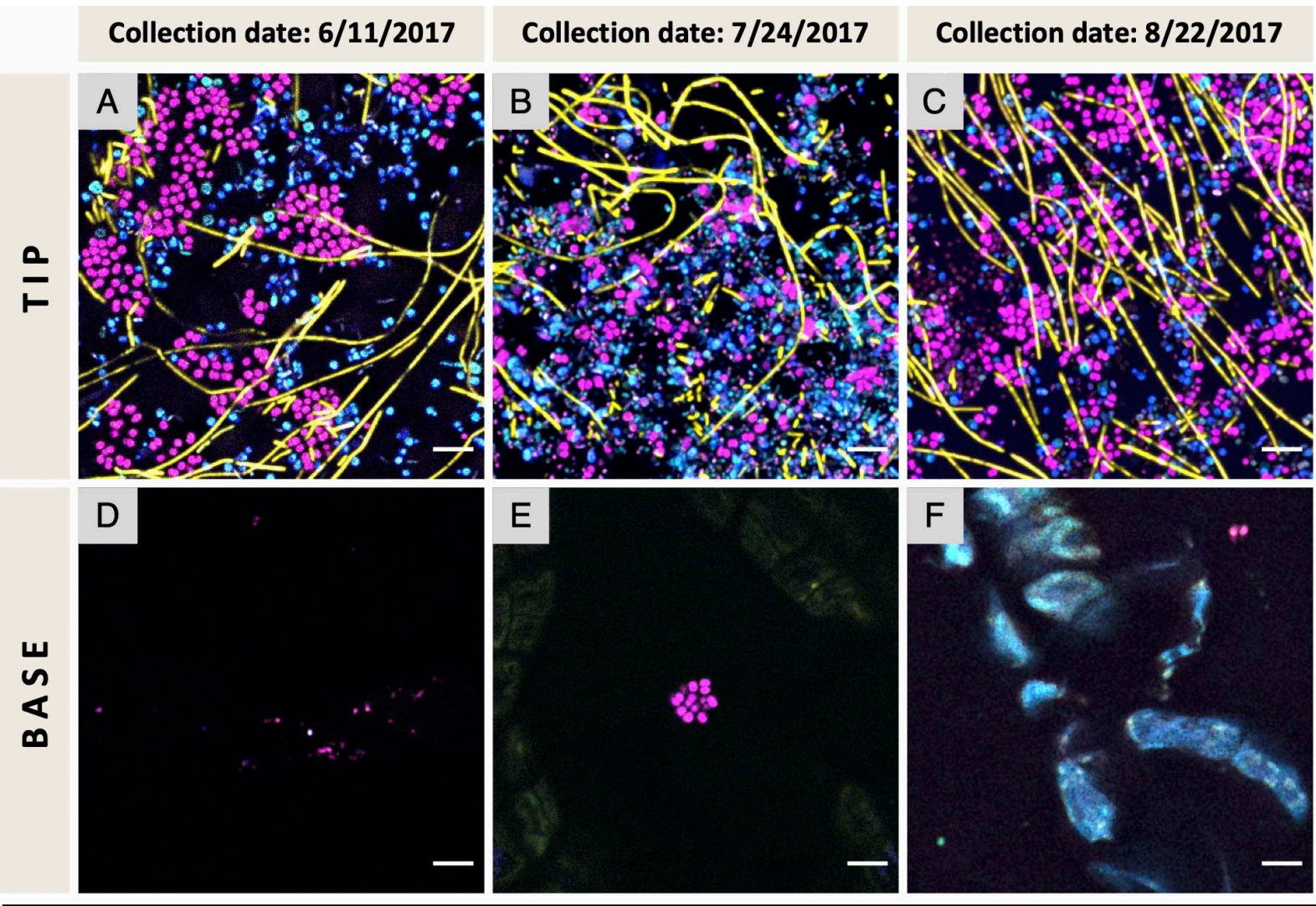

Alphaproteobacteria Bacteroidetes Granulosicoccus Verrucomicrobia-Planctomycetes Autofluorescence

690 Figure 3. Bacterial abundance of the surface biofilm in old and young tissue. Whole-mount

691 images of tip and base tissues collected from the same kelp frond. Three individuals from

692 different collection dates are shown. Older tissue of the tip (A, B, C) is densely colonized 693 compared to young tissue of the base (D, E, F). The same pattern is observed throughout the 694 summer. Scale bar $=5 \mu \mathrm{m}(\mathrm{A}-\mathrm{F})$. 

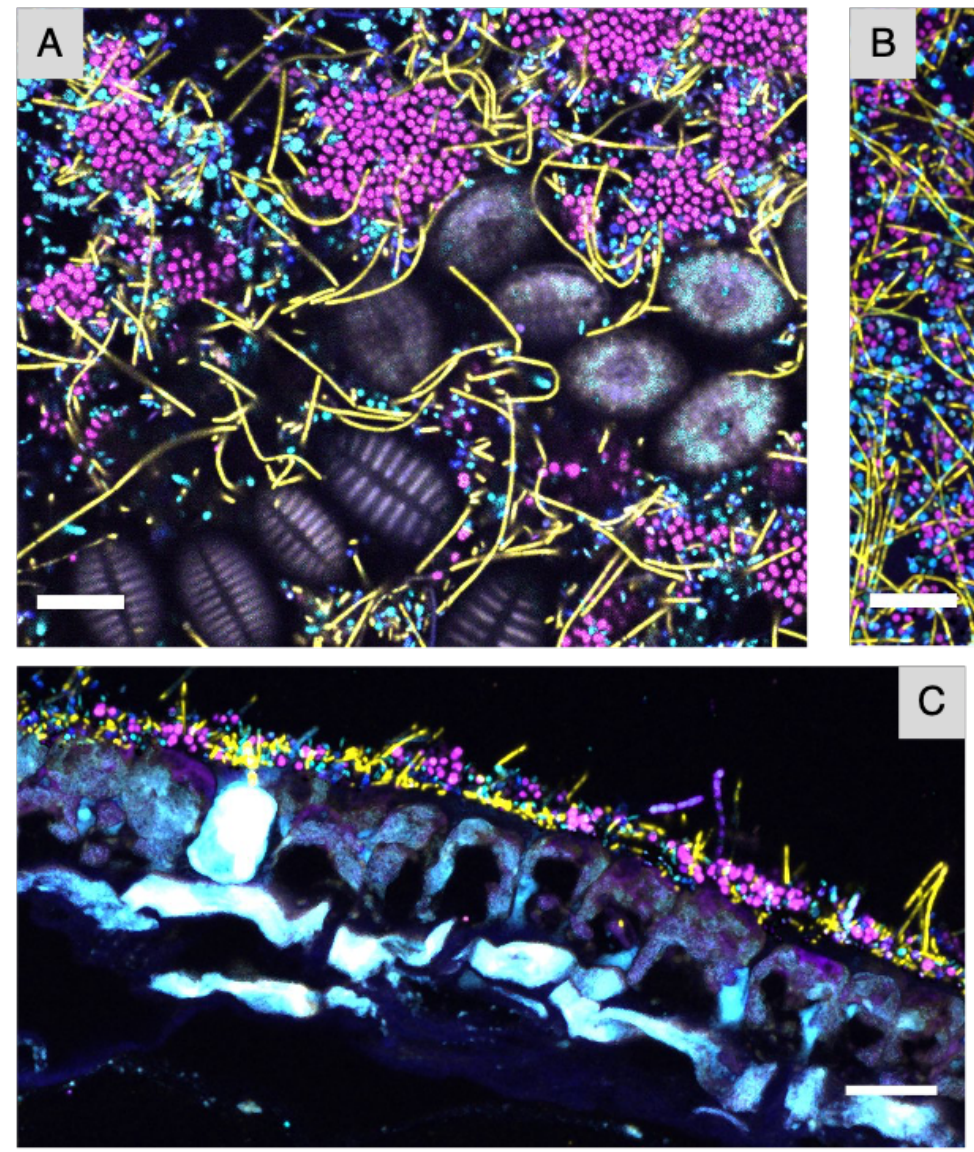

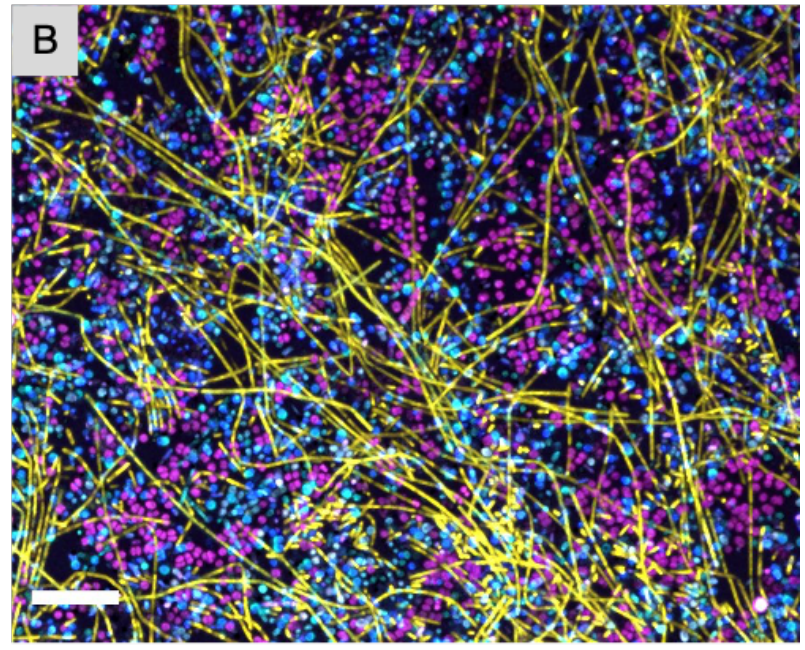

Alphaproteobacteria Bacteroidetes Granulosicoccus

VerrucomicrobiaPlanctomycetes Gammaproteobacteria Autofluorescence (in A, B) Autofluorescence (in C)

Figure 4. Spatial structure of the epiphytic microbial community at the tip of $N$. luetkeana

blades. Bacteria at the tip of kelp blades form a dense biofilm. (A) and (B) show whole-mount

697 images of samples collected in different dates; (C) is a cross-section showing thickness of the

698 surface biofilm. Microorganisms are intermixed, often directly adjacent to cells of disparate taxa

699 and always within 10 microns of other taxa. Granulosicoccus aggregate in clusters while other

700 taxa are more dispersed. Abundant Bacteroidetes filaments appear to be lying on the other taxa in

701 the whole mount and are visible in the cross-section, together with filaments of

702 Gammaproteobacteria, projecting into the water column. Diatoms surrounded by bacteria are

703 visible in $(\mathrm{A})$.

704 Scale bar $=10 \mu \mathrm{m}(\mathrm{A}),(\mathrm{B})$ and (C). 

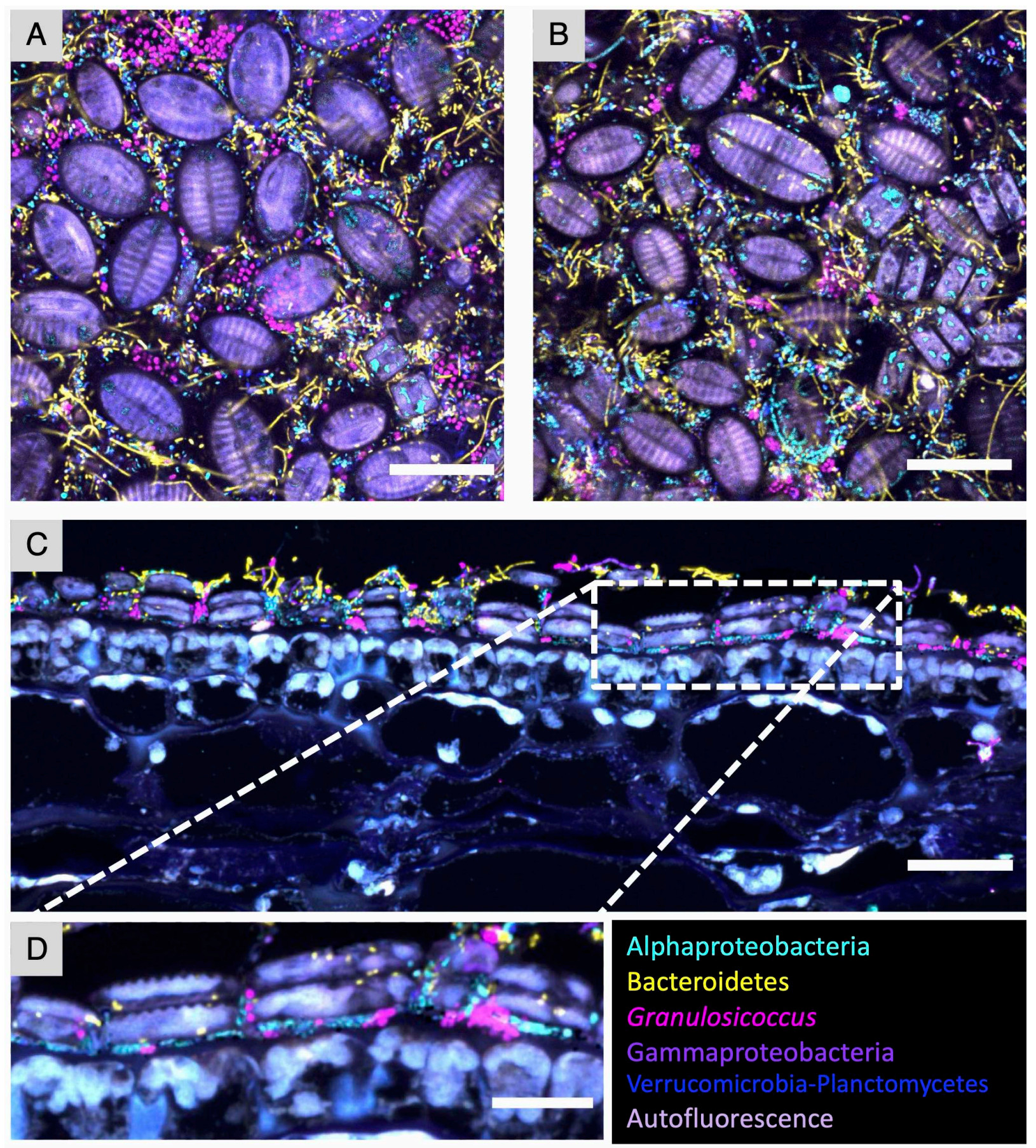

705 Figure 5. Diatoms are part of the microbial community of $\boldsymbol{N}$. luetkeana. Colonies of diatoms

706 were observed on kelp blades in samples from June and July. (A) and (B) Representative images

707 of whole-mount FISH showing diatoms surrounded by bacteria. (C) Cross-section showing

708 diatoms embedded within the bacterial biofilm. (D) Enlarged image of the dashed rectangle in

709 (C). No specific association between diatoms and particular taxa was observed.

$710 \quad$ Scale bar $=20 \mu \mathrm{m}(\mathrm{A}-\mathrm{C}) ; 10 \mu \mathrm{m}(\mathrm{D})$. 

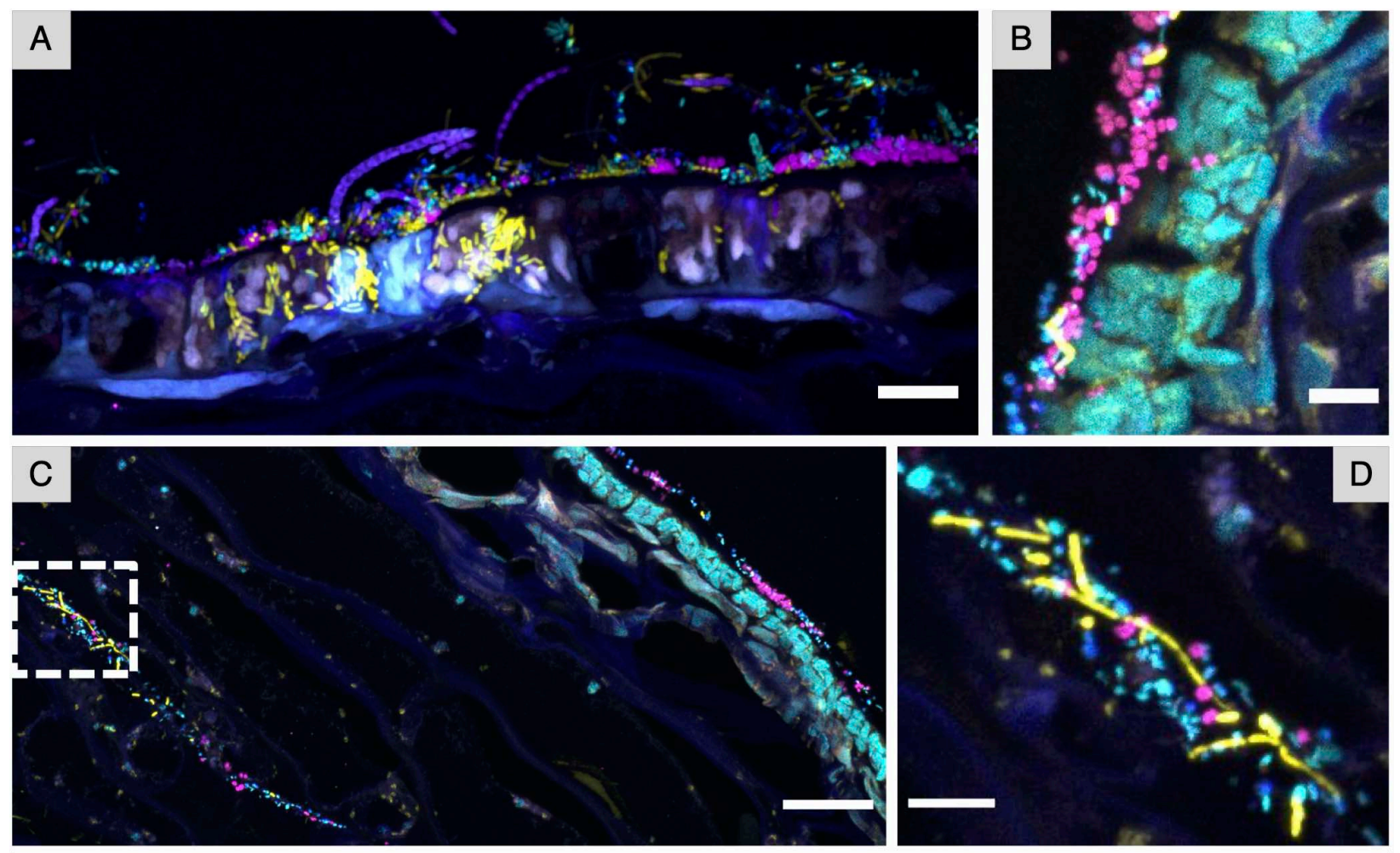

Alphaproteobacteria Bacteroidetes Granulosicoccus Verrucomicrobia-Planctomycetes Gammaproteobacteria Autofluorescence

711 Figure 6. Endophytic bacteria of N. luetkeana. (A) Cross-section showing Bacteroidetes rods

712 colonizing intercellular spaces of brightly autofluorescent kelp surface cells. (B) A region in

713 which the biofilm is directly adjacent to the kelp tissue and some Granulosicoccus are observed

714 between kelp cells. (C) Bacteria were also detected colonizing deeper areas of the tissue, in this

715 instance around $120 \mu \mathrm{m}$ from the surface. (D) enlarged image of the dashed rectangle in (C).

716 Scale bar $=10 \mu \mathrm{m}(\mathrm{A}) ; 5 \mu \mathrm{m}$ (B) and (D); $20 \mu \mathrm{m}(\mathrm{C})$. 

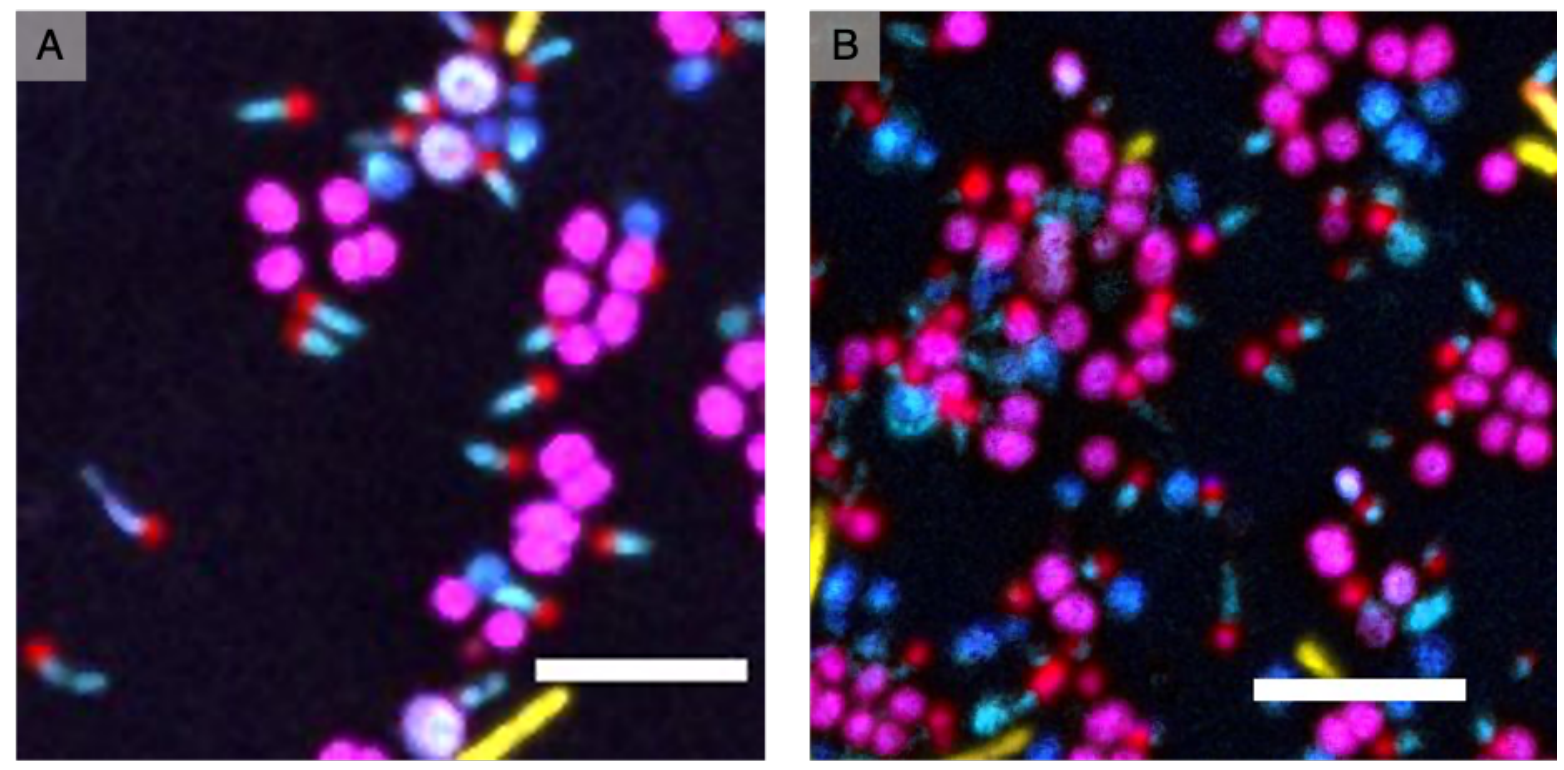

Alphaproteobacteria Bacteroidetes Granulosicoccus Verrucomicrobia-Planctomycetes Wheat Germ Agglutinin Autofluorescence

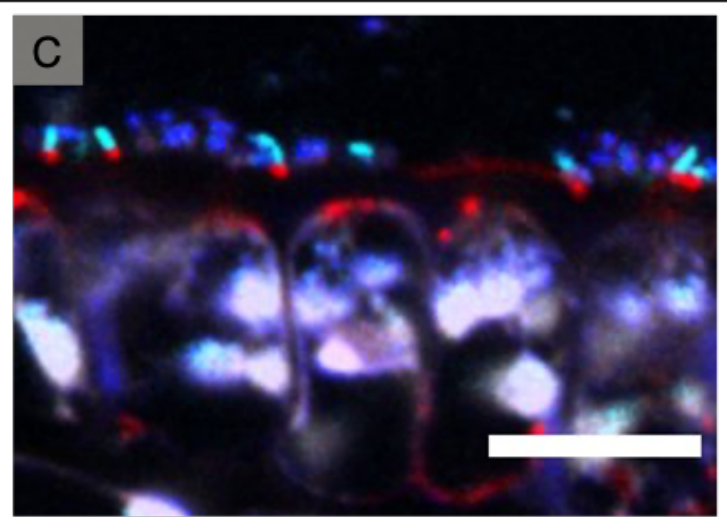

Alphaproteobacteria

Wheat Germ Agglutinin

Other bacteria

Autofluorescence

717 Figure 7. Unipolar labeling of adherent Alphaproteobacteria by wheat germ agglutinin.

718 Wheat germ agglutinin was used to stain $\mathrm{N}$-acetylglucosamine and $\mathrm{N}$-acetylmuramic acid

719 residues. Staining was observed on Alphaproteobacteria rods at only one end showing apparent

720 polarity with respect to the cells. (A) and (B) Representative images of whole-mount FISH in

721 samples collected in different months. (C) Cross-section image showing Alphaproteobacteria

722 rods with the polar polysaccharide end attached to the kelp surface.

723 Scale bar=5 $\mu \mathrm{m}(\mathrm{A})$ and (B); $10 \mu \mathrm{m}(\mathrm{C})$. 

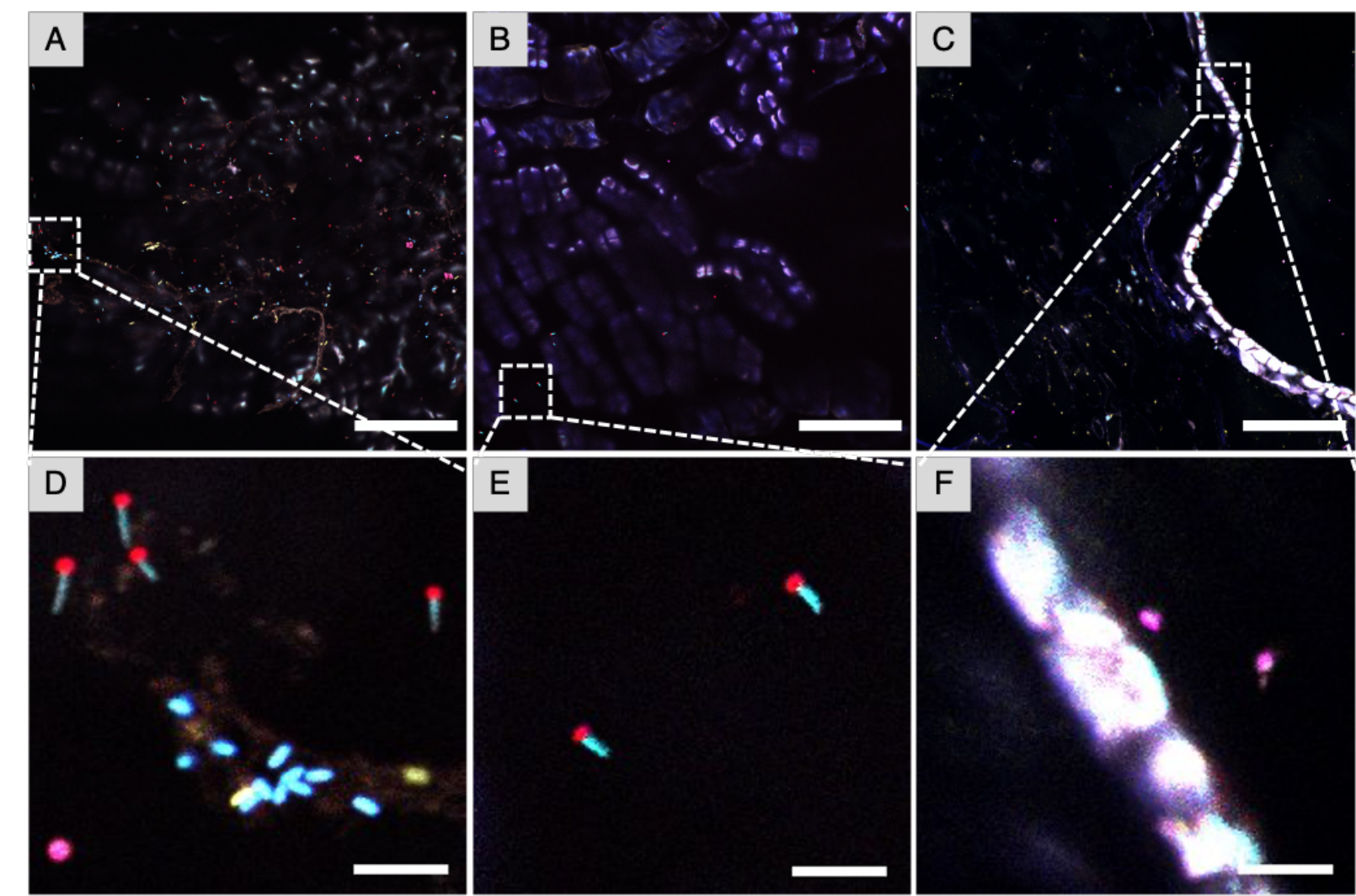

Alphaproteobacteria Bacteroidetes Granulosicoccus Verrucomicrobia-Planctomycetes Wheat Germ Agglutinin Autofluorescence

724 Figure 8. Low microbial density on declining population of kelp in Squaxin Island. (A) and

725 (B) whole mount FISH showing sparse bacteria on kelp surface. (C) Cross-section in which no

726 dense biofilm is observed on the surface, but a few bacteria were visible. Strong

727 autofluorescence of kelp cells is observed. (D), (E) and (F) are enlarged images of the dashed

728 squares in (A), (B), and (C), respectively.

$729 \quad$ Scale bar $=20 \mu \mathrm{m}(\mathrm{A}-\mathrm{C}) ; 5 \mu \mathrm{m}(\mathrm{D}-\mathrm{F})$. 
731 Table 1. Probes used in this study.

\begin{tabular}{|c|c|c|c|c|}
\hline Probe & Target taxon & Probe sequence 5' -3 & Fluorophore & Reference \\
\hline Eub338-I & Bacteria & GCTGCCTCCCGTAGGAGT & $\begin{array}{l}\text { Dy490, } \\
\text { Atto532 }\end{array}$ & $\begin{array}{l}\text { Amann et } \\
\text { al. } 1990\end{array}$ \\
\hline Eub338-II & Planctomycetes & GCAGCCACCCGTAGGTGT & Dy415 & $\begin{array}{l}\text { Daims et } \\
\text { al. } 1999\end{array}$ \\
\hline Eub338-III & Verrucomicrobia & GCTGCCACCCGTAGGTGT & Dy415 & $\begin{array}{l}\text { Daims et } \\
\text { al. } 1999\end{array}$ \\
\hline Alf968 & Alphaproteobacteria & GGTAAGGTTCTGCGCGTT & $\begin{array}{l}\text { Dy490, } \\
\text { Atto620 }\end{array}$ & $\begin{array}{l}\text { Neef A. } \\
1997\end{array}$ \\
\hline Gam42a & Gammaproteobacteria & GCCTTCCCACATCGTTT & Cy5 & $\begin{array}{l}\text { Manz et } \\
\text { al. } 1992\end{array}$ \\
\hline Bac1058 & Bacteroidetes & TGAATGGCTGCTTCCAAGCCAACA & $\begin{array}{l}\text { Rhodamine } \\
\text { Red-X }\end{array}$ & $\begin{array}{l}\text { Schlundt } \\
\text { et al. } 2019\end{array}$ \\
\hline Gran737 & Granulosicoccus spp. & TCAGCGTCAGTATTGTTCCAGA & Texas Red-X & This study \\
\hline Gran670 & Granulosicoccus spp. & CACCGCTACACCCGGAATTCCGC & Texas Red-X & This study \\
\hline
\end{tabular}


732 Table 2. Cell size, abundance and spatial correlation using linear dipole analysis in daime across

7338 individuals ( $\mathrm{n}=2-13$ replicates each) in images $212.55 \mu \mathrm{m}$ on a side. Means (SD) are given.

734 Cell abundances were positively correlated within and among the two species, indicating

735 clumped distributions. The distribution of correlations with distance are shown in FigS3.

\begin{tabular}{|l|c|c|l|c|}
\hline Probe & $\begin{array}{l}\text { Cell size in } \\
\mu \mathrm{m}\end{array}$ & Cell Abundance & $\begin{array}{l}\text { Distances of } \\
\text { spatial } \\
\text { autocorrelation }\end{array}$ & $\begin{array}{l}\text { Distances of } \\
\text { spatial cross } \\
\text { correlation }\end{array}$ \\
\hline Granulosicoccus & $0.47(0.23)$ & $4025.3(3416.7)$ & $<9 \mu \mathrm{m}$ & - \\
\hline Verrucomicrobia & $0.42(0.16)$ & $2445.3(1142.2)$ & $<7 \mu \mathrm{m}$ & - \\
\hline $\begin{array}{l}\text { Granulosiccus vs. } \\
\text { Verrucomicrobia }\end{array}$ & - & - & - & $<5 \mu \mathrm{m}$ \\
\hline
\end{tabular}

